\title{
Study on the Pattern and Development Trend of River- Chief Mechanism in Cross-Boundary Governance from the Perspective of Holistic Governance
}

\author{
Ke Zhang, * \\ ${ }^{1}$ University of Electronic Science and Technology of China \\ *Corresponding author. Email: aitelan@126.com
}

\begin{abstract}
With the development of the times, the boundaries of public affairs gradually extend outward. Faced with complex public affairs, the ability of a single government department to deal with problems is limited. The cross-boundary governance brings an effective way of governance. The river-chief mechanism which is a kind of concrete pattern of cross-boundary governance solves the problem that cannot be solved by a single body. The river-chief mechanism has existence significance.

From the perspective of holistic governance, this paper analyzes the logic of holistic governance in solving problems. Then the paper takes the river-chief mechanism of Bengbu as an example and analyzes the river-chief mechanism of Bengbu is an integrated and coordinated model with relevant data. Finally, the paper looks forward to the future trend of river-chief mechanism from the perspective of holistic governance : the long effect trend of legal system construction, the synergy trend of mechanism of department coordination and integration and the diversified trend of public participation. According to the research of river-chief mechanism of Bengbu, the paper can provide some reference for other places to implement river-chief mechanism.
\end{abstract}

Keywords: Holistic governance, Cross-boundary governance, River-chief

\section{INTRODUCTION}

Due to changes in the times, society has gradually become open, fluid, and changeable. On this basis, public affairs are no longer confined to a single field or region, and the people, events, and things involved may also belong to different categories. In order to better solve similar cross-domain issues, local governments have gradually begun to adopt cross-domain governance. mode. Among the public affairs involved in crossdomain governance, watershed governance is relatively representative. Since the objects involved in watershed governance usually cover a wide range, governance by a single local government department is obviously not appropriate. In order to solve the problem of watershed governance, The river-chief mechanism came into being. As a specific system model for river basin governance, the general practice of the "River Chief Mechanism" means that the main leaders of the local party and government at all levels serve as the "river chief" of the rivers in the jurisdiction, responsible for the pollution control and water quality protection of the rivers in the jurisdiction $^{[1]}$. As an innovative system model, the river chief has its shortcomings, so in this article, the author tries to analyze the river chief mechanism from the perspective of overall governance ${ }^{[2]}$. As a means of solving problems, holistic governance is mainly proposed for fragmentation problems. Fragmentation usually exists in cross-domain governance. Fragmentation refers to the barriers of division between various government departments and it is difficult to coordinate and integrate ${ }^{[3]}$. When studying the fragmentation of cross-domain governance, this article mainly refers to the problems that exist between different governments, between different government departments, between the government and other organizations, and between the government and the people.

\section{METHODS}

The article mainly adopts the literature research method, interview method, and case study method. First, collect the data of the river chief system of Bengbu City through a variety of methods, carry out screening and 
summary, then analyze the current situation of the river chief system of Bengbu City, and discuss it from the perspective of overall governance The current shortcomings, perfect measures, and finally from the small to the big, look forward to the future development trend of the river chief system.

\section{BASIC SITUATION OF THE RIVER- CHIEF MECHANISM IN BENGBU}

In the organizational structure of the river chief system of Bengbu, river chiefs are set up according to different levels. Each level has a corresponding river chief and river chief system office, and regular meetings of river chiefs are held. The head of the river, the deputy head of the river, and related staff are jointly composed. Normally, the city-level river chiefs' meeting is once a year, and the city-level river chiefs' meeting is twice a year. The location of the city-level river chief system office of Bengbu is located in Bengbu Water Resources Bureau.

In the distribution of powers and responsibilities in the Bengbu river chief system, the river chief is responsible for leading and organizing corresponding work. The main tasks of the river chief are to solve major problems that occur in the river basin within the scope of his management, to rectify the relatively serious problems in accordance with the law, to supervise the work of the lower-level responsible persons and to conduct regular assessments.

From the perspective of the main tasks of the implementation of the river chief system in Bengbu City, it can be divided into six points: strengthening water resources management and protection, strengthening river and lake shoreline management and protection, strengthening water pollution prevention and control, strengthening water environment management, strengthening water ecological restoration, and strengthening Law enforcement supervision.

\section{INTEGRATED AND COORDINATED MODEL: ANALYSIS ON THE MODE OF RIVER CHIEF SYSTEM IN BENGBU}

\subsection{Reasons for the formation of an integrated and coordinated model}

\subsubsection{Central Promotion}

The river chief system is not a system planned and implemented by Bengbu to solve river basin problems. Instead, the central government issued a document at the end of 2016 requiring the implementation of the river chief system nationwide before Bengbu began to obey the order and implement the river chief system. As one of the important prefecture-level cities in Anhui Province, and as the seat of the Huai River Water Conservancy
Commission, Bengbu naturally has to become an example of the successful implementation of the river chief system in Anhui Province. Facing such higher-level requirements, Bengbu needs to complete the task on time.

\subsubsection{Lack of Water Resources}

Bengbu City seems to have sufficient water resources, but due to the large seasonal difference in precipitation, it usually rains in summer, and floods often occur during the flood season. At this time, it is difficult to convert water resources into valuable water resources, so seasonal Sexual water shortage and other issues. Bengbu is a national-level ecological civilization pilot demonstration zone and the second batch of national water ecological civilization construction pilot cities. The current shortage of available water resources and excessive dependence on seasonal changes have affected the sustainable development of Bengbu. Solving these problems is Urgently, the traditional watershed governance model has many deficiencies that are difficult to solve. The river chief system with successful local experience is more suitable for the current situation of Bengbu.

\subsubsection{People's Demand}

One of the important foundations of holistic governance is that the behavior of government agencies is oriented toward the issues that the people are most concerned and worried about. A policy search for the term "water environment" on the official website of the Central People's Government of the People's Republic of China revealed a total of 99 relevant policy documents, of which 23 were from 2017 to 2019. The earliest relevant policy that can be found is In 2005, 99 related policies spanned 15 years. It can be seen that the state has attached great importance to water environment related issues in recent years, and the state's attention comes from the needs of the people.

\subsection{Integrated and Coordinated Model of Operation Ideas}

Under the logic of holistic governance, a central idea is "the logical basis of government action lies in the solution of problems", and the three basic premises are: the people have needs and require the government to solve them, and the behavior of government departments is based on the people's concerns and solutions People's problems require integration and coordination among various government departments. Simply put, government behavior is result-oriented. On this basis, the government needs to coordinate and integrate departments to achieve its goals. This may make it easier to solve the public problems that the people need the government to solve. 
The integrated and coordinated river chief system reflects the overall operation of the government. The member units of the Bengbu Municipal River Chiefs Meeting are 14 units including the Municipal Development and Reform Commission, the Municipal Economic and Information Commission, the Municipal Public Security Bureau, and the Municipal Finance Bureau. Each member unit has designated a section-level cadre as a liaison officer. It can be seen from this that in the process of implementing the river chief system, all functional departments that may be involved in river governance issues are included, and an integrated new organization is established.

The Bengbu River Chief System re-divided the organizational system from the perspective of holistic governance, so that government departments that originally did not interfere with each other and worked independently were coordinated and integrated. This river chief system model embodies the problem as the starting point to formulate future goals, and then analyze the conditions required to achieve this established goal. Under the condition that the two ends remain unchanged, the intermediate links can be flexibly changed, as long as the problem starts from the problem. Loyal to the results, the specific process and how to achieve the goal can be adjusted.

\section{THE DEVELOPMENT TREND OF RIVER-CHIEF MECHANISM FROM THE PERSPECTIVE OF HOLISTIC GOVERNANCE}

\subsection{The Long Effect Trend of Legal System Construction}

From the perspective of the current local legal system construction, only a few provinces and cities have stipulated the river chief system in the legal system, in order to ensure its long-term operation and achieve for the purpose of continuous governance, it is necessary to consider how to ensure the long-term effectiveness of the river chief system. In order to solve this, we must first proceed from the construction of the legal system.

First of all, we must further improve and refine the existing laws. The central government must first take the lead to apply the experience accumulated in the implementation of the river chief system over the years, and clearly regulate the relevant content of the river chief system in the form of law, including the river chief system. The specific rights and obligations of the "River Chief", the establishment of the "River Chief Committee", the composition of the organization and the construction of the organizational system, etc., need to be clarified in the form of laws and regulations, so that the river Chief system has clear legal protection. While improving the legal system, it is necessary to pay attention to the scope and scale of control. Due to the different actual conditions in different regions, the difficulties in the implementation of the river chief system are also different. In order to reduce the cost increase caused by the overly cumbersome law, it is necessary the local government should be given certain discretion. When establishing the river chief legal system, the local government must ensure that the central government's purpose and framework remain unchanged, and the details can be adjusted. On the basis of complying with laws and regulations, combined with actual flexible adjustments, it can help local governments not only comply with the norms when implementing the river chief system, avoid the chaos of local governance logic, but also without losing flexibility and efficiency, and avoid the failure of the river chief system. Into the stereotyped paradigm under administrative power.

\subsection{The Synergy Trend of Mechanism of Department Coordination and Integration}

The coordination stage requires all departments to ensure information sharing and eliminate the cognitive gap between departments, so that different departments stand at the same starting point. In the integration phase, all departments need to take corresponding practical actions in accordance with the common cognition formed in the coordination phase, and be result-oriented. You can try to form a "community of interest" first. In the river chief system, each department will be evaluated by the superior department. At this time, the work performance can be the common interest of all departments. Furthermore, various departments need to maintain longterm cooperation. At present, the river chief system has been widely implemented. On this basis, various departments have achieved a certain degree of runningin. In the process of cooperation, various departments need to gradually form a trust relationship and find a common ideological basis. For government departments, this ideological basis is the public interest. With the establishment of trust and the discovery of common ideas, the formation of shared concepts will be just around the corner, and finally a "community similar to the river chief system" will be formed. The establishment of the community is to rely on common knowledge and common value perception, and ultimately bring common practical actions.

\subsection{The Diversified Trend of Public Participation}

The river chief system is absent at the social public level. As one of the main bodies other than the relevant government departments, the public lacks in-depth implementation of the river chief system because it is not directly contacted and handled by personnel related to the river chief system. It is understood that in order to improve work efficiency, the government will place the public outside the main work of the implementation of 
the river chief system. If things go on like this, the public will become less and less aware of the river chief system and eventually fall into a vicious circle. Essentially, the river chief system is to assign powers and responsibilities to the river chief, but under the administrative system, the governance model that only relies on government personnel is prone to problems such as information asymmetry and lack of supervision. In order to truly realize the governance of the river basin Purpose, need to ensure the diversity of governance subjects.

In order to solve the problem of lack of public participation, the first thing to be solved is the information asymmetry between the government and the public. The extensive participation of the public is based on diversified communication methods, and is fundamentally the exchange of information between the two parties. Through the "Internet + River Chief System" model, the use of network platforms to promote public participation in the supervision of the River Chief System, and the introduction of third parties can also put a certain pressure on government departments to promote better work afterwards.

\section{CONCLUSION}

Based on the research on the river chief system of Bengbu City, this article can conclude that the river chief system of Bengbu City is an integrated and coordinated model. The central idea of this model is "government action". The logical basis of the company lies in the solution of the problem", achieving the goal through integration and coordination.

\section{REFERENCES}

[1] Aibao Huang. "River Chief System": Institutional Forms and Innovation Trends. Academia Bimestris, 2015, pp, (04), 141-147. DOI:10.16091/j.cnki.cn321308/c.2015.04.019.

[2] Yungui Shi, Quan Zhou. Holistic governance: combing, reflection and trend. Journal of Tianjin Administration Institute, 2014, (05) ,3-8. DOI:10.16326/j.cnki.1008-7168.2014.05.008.

[3] Fanjun Zeng. On the Deep Core of Holistic Governance and Solutions to Fragmentation Problems. Academic Forum, 2010, (10), 32-36+56. DOI:10.16524/j.45-1002.2010.10.016. 